\title{
HUBUNGAN KAUSAL ANTARA KEPEMILIKAN MANAJERIAL, DEWAN DIREKSI DAN KINERJA KEUANGAN PADA PERUSAHAAN MANUFAKTUR YANG TERDAFTAR DI BURSA EFEK INDONESIA
}

\author{
Julastari ${ }^{1)}$,Aminar Sutra Dewi, ${ }^{2)}$ \\ Sekolah Tinggi Ilmu Ekonomi "KBP" \\ Email :julastari07@gmail.com \\ Email Pembimbing :aminarsutradewi@akbpstie.oc.id
}

\begin{abstract}
The composition of managerial ownership can contribute effectively to the results of the process of preparing a quality financial report or the possibility of avoiding fraudulent financial statements. This study aims to determine the effect of Managerial Ownership, Board of Directors, and the influence of Corporate Financial Performance. The sample used was financial sector companies in 2013-2017 totaling 19 samples. The type of data used was secondary data. The hypothesis in this study was tested using panel data regression. The results of hypothesis testing indicate that Managerial Ownership has a negative and not significant effect on Financial Performance (ROA), the Board of Directors has a positive and significant influence on the company's Financial Performance (ROA)
\end{abstract}

Keywords:Managerial Ownership, Board of Directors, and ROA

\section{PENDAHULUAN}

Di saat ini prospek dalam perusahaan disebut juga sebagai kinerja keuangan perusahaan. Perusahaan ini sangat berpotensi dalam pertumbuhanperusahaan terutama informasi yang dibutuhkandan menilai suatu perubahaan potensi sumber daya ekonomiyang dilihat dalam kinerja keuangan, miskipun dapat dikendalikan dalam prospek dan untuk memprediksi kapasitas produksi darisumber daya yang ada. Sedangkan laporan dalam keuangan yang sudah dianalisis sangat diperlukan oleh pemimpin perusahaan bahkan manajemen dan dewan direksi untuk dijadikan alat-alat pengambilan keputusan yang akan datang.

Kinerja keuangan adalah suatu ukuran yang keberhasilannya atas kemampuan dalam fungsi-fungsi keuangan ini sangat penting, baik bagi investor maupun bagi perusahaan. Penilaian prestasi kinerja perusahaan ini sangat pentingdilakukandalam analisa terhadap laporan keuangan yang menjadi pemicu pemikiran para pemimpin perusahaan bahwa dalam tata pengelolaan perusahaan sekarang ini dengan berkembangnya teknologi yang sangat cepat,sehingga menjadi suatu yang lengkap bagi perusahaan dalam melakukan tata kelolaan perusahaan. Jika Semakin lengkap dalam kegiatan pengelolaan perusahaan maka akan meningkatnya kebutuhandalam praktik tata kelolaan perusahaan yang memastikan apakah manajemen terlaksana dengan baik (Noviawan \& Septiani, 2013).

Kinerja keuangan merupakan suatuproses pengkajian yang kritis terhadap keuangan perusahaan yaitu secara review data, menghitung, mengukur, menginterpretasi, dan memberi solusi terhadap keuangan dalam suatu perusahaan dengan periode tertentu. Pengukuran kinerja ini digunakan untuk menekan perilaku agar tidak memberikan dan suaturangsangan serta mendirikan perilaku yang semestinya. Semua ini dilakukanagar dapat memberikan 
motivasidanrangsangan pada masing-masing bagian untuk bekerja lebih efektif dan efisien (Widyati, 2013).

Kinerja keuangan bagi investor suatu perusahaan adalah melihat kinerja yangdihasilkan dalam sektor keuangan berjalan dengan baik. Oleh karena itu perusahaan berkewajiban melakukan pengungkapan kinerja keuangan secara transparan atau tidak disembunyikan berupa Laporan Keuangan. Laporan Keuangan adalah yang memberikan bentuk informasi serta menggambarkan kondisi Kinerja dari perusahaan sehingga dapat dijadikan sebagai bentuk dari prestasi. Kinerja perusahaan mewakili kemajuan maupun kemunduran suatu perusahaan. Kinerja keuangan merupakan hasil dari berbagai keputusan secara perorangan yang dibuat terus menerus oleh manajemen (Dewi, Sari, \& Abaharis, 2018)

Kinerja keuangan yang dirinci dari rasio profitabilitas seperti ReturnonAsset (ROA), Returnon Equity (ROE), dan Net Profit margin (NPM). Penelitian ini merupakan suatu kinerja perusahaan dalam mengukuryang menggunakan ReturnonAsset (ROA). ROA adalah suatu alat ukur dalam kemampuan manajemen perusahaan agar memperoleh keuntungan serta memanfaatkan keseluruhan total aset yang dimiliki. ROA mengukur seberapa banyak yang lebih efektif dari perusahaan yang dapat dirubah pendapatannya dari pengembalian investasi itu sendiri yang akan dijadikan asset. Semakin tinggi ROA perusahaan maka semakin baik untuk perusahaan tersebut. Beberapa perusahaan menekankan net margin yang tinggi untuk meningkatkan ROA tersebut (Tertius \& Chris Austitiawan, 2010).

Di Indonesia, kinerja keuangan perlu dilakukan pengawasan terhadap suatu perusahaan dalam sektor keuangan. Oleh sebab itu, indonesia perlu memiliki system keuangan yang stabil secara fundamental dan berkesinambungan. Dalam pengawasan di sektor keuangan ini perlu diawasi agar dapat melindungi terutama kepentingan konsumen dan masyarakat. Selain itu, kinerja keuangan perusahaan disebut juga suatu penentuan yang mengukur suatu hal yang baik maupun buruk suatu perusahaan dalam prestasi kerja yang dilihat dari kondisi keuangannya pada periode tertentu. Dalam kondisi suatu keuangan dapat dianalisa berdasarkan alat-alat analisis keuangan.

Isu perusahaan manufaktur di Bursa Efek Indonesia ekonomi Universitas Indonesia (UI) dalam pertumbuhan industri manufaktur menunjuktinggi. Karena, sektor ini berpengaruh terhadap energi baru yang bisa mendorong peningkatan ekonomi serta belanja masyarakat meningkat. Perusahaan industri manufaktur merupakan tulang punggung terhadap pertumbuhan nasional. Maka dapat dikatakan diakselerasi, ekonomi tidak hanya tumbuh 5\% tapi bisa lebih, terutama dalam kerja sama suatu perusahaan yang memberikan gambaran bahwa sektor penghasil barang dapat dikatakan kurang baik, bahkan mengalami penurunan dari tahun ke tahun. Setelah krisis, industri manufaktur selalu tumbuh di bawah Produk Domestik Bruto (PDB).Sehingga Indonesia tidak bisa menjadi negara industri. Justru pertumbuhan sektor jasa nasional yang baik. Ada sebagaian perusahaan industri manufaktur yang dikatakan cemerlang dalam pertumbuhannya Pertama, sektor makanan dan minuman.Kedua, sektor kimia, farmasi serta sektor botanical produk. Ketiga, sektor industri komputer, optik dan elektronik. Keempat, sektor transportasi. Perusahaanmanufaktur ini berkembang di atas rata-rata dan pertumbuhan yang sangat cepat dapat mencerminkan selama ini. Namun, hal itu belum bisa menolong pertumbuhan ekonomi nasional secara umum.

Menurut teori Keagenan (AgencyTheory), Jensen dan Meckling (Luayyi, 2010) menjelaskan bahwa hubungan keagenan (agencyrelationship) sebagai suatu kontrak antara pemilik (principal) dengan manajer (agent) untuk menjalankan suatu tugas demi kepentingan pemilik (principal)dengan mendelegasikan wewenang pengambilan keputusan kepada manajer 
(agent). Secara umum manajer sebagai pengelola perusahaan tentunya mengetahui lebih banyak informasi internal dan prospek perusahaan di waktu mendatang dibandingkan pemilik modal atau pemegang saham. Oleh karena itu, sebagai pengelola, manajer memiliki kewajiban memberikan informasi mengenai kondisi perusahaan kepada pemilik. Adapun dalam informasi yang disampaikan oleh manajer terkadang tidak sesuai dengan kondisi perusahaan yang sebenarnya (Pricilia \& Susanto, 2017).

Corporate governance merupakan konsep yang didasarkan pada teori keagenan, sehingga diharapkan bisa berfungsi sebagai alat untuk memberikan keyakinan kepada para investor bahwa mereka akan menerima return atas dana yang telah mereka investasikan. Shleifer dan Vishny (Ujiyantho dan Bambang, 2007) mengatakan bahwa corporate governance berkaitan dengan para investor bagaimana cara meyakinkan bahwa manajer akan memberikan keuntungan untuk mereka, bagi manajer tidak akan mencuri atau menggelapkan atau menginvestasikan ke dalam proyek-proyek yang tidak menguntungkan sehingga berkaitan dengan dana yang telah ditanamkan oleh investor dan berkaitan dengan para investor yang mengontrol para manajer.

Corporate governance diharapkan dapat berfungsi untuk menekankan atau menurunkan biaya keagenan (agencycost). Menurut Susanto ( 2017), ada tujuh mekanisme dalam mengukur corporategovernance, yaitu kepemilikan institusional, kepemilikan manajerial, dewan komisaris, dewan direksi, dewan komisaris independen, ukuran perusahaan dan komite audit. Dalam penelitian ini ukuran kinerja keuangan yang digunakan adalah kepemilikan manajerial dan dewan direksi (Widyati, 2013).

\section{Keterkaitan Kepemilikan Manjerial Terhadap Kinerja Keuangan}

Kepemilikan manajerial adalah orang-orang yang berkedudukan atas bisa lebih konsisten dalam menjalankan perusahaan apabila bisa menyamakan kepentingan menejer dan pemilik saham sehingga dapat meningkatkan kinerja perusahaan (Puspitasari \& Ernawati, 2010).

Kinerja keuangan merupakan ukuran perusahaan untuk melihat pencapaian atas segala bentuk pelaksanaan dari fungsi-fungsi keuangan ini sangatlah penting, bagi investor dan perusahaan(Noviawan \& Septiani, 2013).Jadi,Kepemilikan manejerial terhadap kinerja keuangan adalahmeneliti pengaruhnya kepemilikan saham oleh pihak manajer terhadap prestasi badan usaha dilihat dengan kontrak kompensasi(Puspitasari \& Ernawati, 2010). Lebih lanjut, Hasil penelitian menunjukkan kepemilikan saham oleh pihak manajer memiliki pengaruh signifikan positif terhadap kinerja keuangan.

Adapun jurnal pendukung yang penelitian ini menurut (Noviawan \& Septiani, 2013) tentang pengaruhnya kepemilikan manejerial terhadap kinerja keuanganyang mana hasilnya positif terhadap kinerja keuangan. Menurut Putra (2017), menjelaskan tentang pengaruhnya kepemilikan menejerial terhadap kinerja keuangan yang mana hasilnya positif terhadap nilai perusahaan maupun kinerja keuangan (Puspitasari \& Ernawati, 2010). Lebih lanjut, ia juga mengungkapkan bahwa kepemilikan menejerial terhadap kinerja keuangan yang mana hasilnya menyatakanmanajer memiliki pengaruh signifikan positif terhadap kinerja keuangan (kombinasi dari ROA, ROE, PER). Hasil penelitian (Widyati, 2013) menyatakan bahwa kepemilikan manajerial berpengaruh signifikan negatif terhadap kinerja keuangan perusahaan. Hasil ini mengindikasikan bahwa baik dewan direksi maupun dewan komisaris memiliki insentif untuk memaksimumkan kesejahteraannya dan konflik yang terjadi di dalam teori keagenan tidak dapat dikurangi

H1 : Diduga Kepemilikan Manajerial berpengaruh positif dan signifikan terhadap Kinerja Keuangan 


\section{Kerterkaitan Dewan Direksi Terhadap Kinerja Keuangan}

Dewan direksi merupakan organ perseroan yang berwenang dan bertanggung jawab penuh atas pengurusan Perseroan untuk kepentingan Perseroan, sesuai dengan maksud dan tujuan, Perseroan serta mewakili Perseroan, baik di dalam maupun di luar pengadilan sesuai dengan ketentuan anggaran dasar (Widyati, 2013).

Kinerja keuangan bagi investor suatu perusahaan adalah melihat kinerja yangdihasilkan dalam sektor keuangan berjalan dengan baik. Oleh karena itu perusahaan berkewajiban melakukan pengungkapan kinerja keuangan secara transparan atau tidak disembunyikan berupa Laporan Keuangan (Rivandi, 2018). Laporan Keuangan adalah yang memberikan bentuk informasi serta menggambarkan kondisi Kinerja dari perusahaan sehingga dapat dijadikan sebagai bentuk dari prestasi. Kinerja perusahaan mewakili kemajuan maupun kemunduran suatu perusahaan. Kinerja keuangan merupakan hasil dari berbagai keputusan secara perorangan yang dibuat terus menerus oleh manajemen (Dewi, Sari, \& Abaharis, 2018)

Adapun jurnal pendukung yang penelitian ini,Putra (2017) mengatakan bahwa dewan direksi terhadap kinerja keuangan yang mana hasilnya menyimpulkan positif terhadap kinerja keuangan perusahaan. Sedangkan menurut Noviawan \& Septiani (2013) mengatakan bahwa pengaruhnya dewan direksi terhadap kinerja keuanagn yang mana hasilnya menyatakan positif dengan kinerja. Selain itu, menurut Dewi (2012) menjelaskan bahwa pengaruhnya dewan direksi terhadap kinerja perusahaan yang mana hasilnya menyatakan bahwa dewan direksi berpengaruh positif terhadap kinerja perusahaan. Sejalan dengan pendapat Sukandar (2014), yang menjelaskan tentang pengaruhnya dewan direksi terhadap kinerja keuangan yang mana hasilnya menyatakan berpengaruh positif terhadap kinerja keuangan.

H2 : Diduga Dewan Direksi berpengaruh positif dan signifikan terhadap Kinerja Keuangan

\section{METODE PENELITIAN}

Penelitian ini dilakukan pada perusahaan yang terdaftar di Bursa Efek Indonesia. Alasan pemilihan obyek ini adalah dalam pemilihan sampel tidak terdapat kendala kekurangan data, dan titik informasi yang pasti mengenai industri yang telah go publik.

Dalam penelitian ini, Annual Report dan Summary digunakan sebagai sumber data utama. Jenis data yang didapatkan dari Annual Report dan Summar yberupa data kuantitatif. Data kuantitatif yang digunakan seperti laporan laba rugi, laporan ekuitas, laporan neraca. Teknik pengumpulan data yang digunakan dalah dokumentasi.

Populasi dalam penelitian ini adalah perusahaan manufaktur yang terdaftar di Bursa Efek Indonesai (BEI) selama periode 2013-2017.Teknik pengambilan sampel yang digunakan adalah purposive sampling. kriteria yang digunakan untuk memilih sampel adalah sebagai berikut :

1 Perusahaan manufaktur sudah terdaftar di Bursa Efek Indonesia diakhir periode observasi padaTahun 2017.

2 Perusahaan Manufaktur sudah terdaftarsecara berturut-turut di Bursa Efek Indonesia pada periode 2013-2017.

3 Perusahaan manufaktur terdapat Informasiterhadap laporan tahunan atau laporan keuangan yang sudah diaudit yang merangkum semua variabel dipakai dalam penelitian. 


\section{Tabel 1}

Seleksi Pengambilan Sampel Menggunakan Porposive Sampling

\begin{tabular}{|c|l|c|}
\hline No & \multicolumn{1}{|c|}{ Kriteria } & Sampel \\
\hline 1. & $\begin{array}{l}\text { Perusahaan manufaktur yang terdaftar di Bursa Efek } \\
\text { Indonesia diakhir periode observasi Tahun 2017 }\end{array}$ & 147 \\
\hline 2. & $\begin{array}{l}\text { PerusahaanManufaktur yang tidak terdaftarsecaraberturut- } \\
\text { turut di bursa efek Indonesia selamaperiode 2013-2017 }\end{array}$ & $(20)$ \\
\hline 3. & $\begin{array}{l}\text { Perusahaan manufaktur yang tidak terdapatInformasi dalam } \\
\text { laporan tahunan atau laporan keuangan yang telah diaudit } \\
\text { mencakup seluruh variabel yang digunakan dalam } \\
\text { penelitian }\end{array}$ & $19 \times 5=95$ \\
\hline 4. & $\begin{array}{l}\text { Jumlah sampel } \\
5 .\end{array}$ & \begin{tabular}{l} 
Jumlah observasi \\
\hline
\end{tabular}
\end{tabular}

\section{Defenisi Operasional Variabel}

Variabel yang digunakan dalam penelitian ini terbagi dua yaitu variabel independen dan variabel dependen. Variabel independen adalah kepemilikan manajerial dan ukuran dewan direksi sedangkan variabel dependennya adalah kinerja keuangan dapat kita lihat tabeldibawah ini :

Tabel 2

Definisi Operasional Penelitian

\begin{tabular}{|c|c|c|c|c|}
\hline No & Variabel & Definisi & Pengukuran & Sumber \\
\hline 1 & $\begin{array}{l}\text { Kepemilikan } \\
\text { Manajerial } \\
\text { (X1) }\end{array}$ & $\begin{array}{l}\text { kepemilikan manajerial } \\
\text { adalah alat pengawasan } \\
\text { kepada kinerja manajer } \\
\text { yang bersifat internal }\end{array}$ & $\begin{array}{l}\text { Persentase } \\
\text { manajerial }\end{array}$ & $\begin{array}{l}\text { (Noviawan } \\
\& \\
\text { Septiani, } \\
\text { 2013) }\end{array}$ \\
\hline 2 & $\begin{array}{l}\text { Dewan } \\
\text { Direksi } \\
(\mathrm{X} 2)\end{array}$ & $\begin{array}{l}\text { Dewan direksi adalah } \\
\text { anggota dewan yang } \\
\text { bertanggung jawab } \\
\text { terhadap kinerja dan } \\
\text { manajemen perusahaan }\end{array}$ & $\begin{array}{lrr}\text { Jumlah } & \text { seluruh } & \text { anggota } \\
\text { dewan } & \text { direksi } & \text { dalam } \\
\text { perusahaan } & & \end{array}$ & $\begin{array}{l}\text { (Noviawan } \\
\& \\
\text { Septiani, } \\
\text { 2013) }\end{array}$ \\
\hline 3 & $\begin{array}{l}\text { Kinerja } \\
\text { keuangan }\end{array}$ & $\begin{array}{lr}\begin{array}{l}\text { Returnon } \\
\text { merupakan }\end{array} & \text { Aset } \\
\text { efoA }) \\
\text { efektivitas } & \text { perusahaan } \\
\text { untuk } & \text { menghasilkan } \\
\end{array}$ & $R O A=\frac{\text { Keuntungan Bersih }}{\text { Jumlahasset }}$ & $\begin{array}{l}\text { (Noviawan } \\
\& \\
\text { Septiani, }\end{array}$ \\
\hline
\end{tabular}




\section{Teknik Analisis Data}

Dalam penelitian ini dilakukan pengujian hipotesis yang bertujuan menguji pengaruh kepemilikan manajerial dan dewan direksi terhadap kinerja keuangan. Data yang digunakan pada penelitian ini yaitu data panel, yang merupakan gabungan antara data timeseries dan crosssection. Data sampel sebanyak 19 perusahaan diambil dari data unit cross section dan data time series periode 2013-2017.

Analisis statistik deskriptif merupakan metode analisis yang digunakan dalam penelitian ini dan menggunakan Program Eviews (Winarno, 2015) untuk analisis regresi data panel. Persamaan regresi data panel yang digunakan dalam penelitian ini adalah:

$$
\mathrm{KK}_{\mathrm{it}}=\boldsymbol{\alpha}+\boldsymbol{\beta}_{1} \mathrm{KM}_{\mathrm{it}}+\boldsymbol{\beta}_{2} \mathrm{DD} \mathrm{D}_{\mathrm{it}}+\mathrm{e}
$$

Keterangan:

$\begin{array}{ll}\mathrm{KK}_{\mathrm{it}} & =\text { Kinerja Keuangan } \\ \alpha & =\text { Konstan } \\ \mathrm{KM}_{\mathrm{it}} & =\text { Kepemilikan Manajerial } \\ \mathrm{DD}_{\mathrm{it}} & =\text { Dewan Direksi } \\ \beta_{1} & =\text { Koefisien Regresi Kepemilikan Manajerial } \\ \beta_{2} & =\text { Koefisien Regresi Dewan Direksi } \\ \mathrm{e} & =\text { Error }\end{array}$

Pendekatan yang dilakukan dalam analisis regresi data panel yaitu Common Effect Model (CEM), Fixed Effect Model (FEM), Random Effect Model ( REM)(Wulandari, 2017). Ada dua tahapan yang dilakukan untuk menentukan model yang terbaik digunakan antara model tersebut yaitu: Chow Test, untuk menentukan model mana yang terbaik antara Common Effect Model (CEM) denganFixed Effect Model (FEM).Hausman Test, dilakukan untuk menentukan model mana yang terbaik digunakan antara Fixed effect Model (FEM) denganRandom Effect Model (REM). Model regresi yang baik harus menghasilkan estimasi linear tidak bias (Best Linear Unbiased Estimator)(Hadya, Begawati, dan Yusra, 2017).

\section{HASIL DAN PEMBAHASAN \\ Hasil Uji Deskripsi Statistik}

Dari hasil analisis deskriptif statistic, maka data karakteristik sampel dipakai didalam penelitian ini adalah jumlah sampel $(\mathrm{N})$, rata-rata sampel (mean), nilai maksimum, nilai minimum serta standar deviasi $(\sigma)$ untuk masing-masing variabel. Berikut hasil uji statistic deskriptif dapat dilihat pada tabel berikut: 
Tabel 3

Uji Statistik Deskriptif

\begin{tabular}{llll}
\hline & KK & KM & DD \\
\hline Mean & 3.067789 & 12.47989 & 4.810526 \\
Median & 1.810000 & 1.620000 & 4.000000 \\
Maximum & 14.69000 & 73.93000 & 12.00000 \\
Minimum & -12.51000 & 0.010000 & 2.000000 \\
Std. Dev. & 5.567039 & 22.98727 & 2.125302 \\
Observations & 95 & 95 & 95 \\
\hline
\end{tabular}

Sumber: outputeviews 8

Pada tabel 3 dapat dilihat bahwa 95 sampel digunakan dalam penelitian ini, data KM Kepemilikan Manajerial (X1), DD Dewan Direksi (X2), dan ROA kinerja keuangan(Y) didapatkan dari laporan keuangan perusahaan manufaktur yang terdaftar di Bursa Efek Indonesia (BEI) periode 2013-2017.

Data Kepemilikan Manajeria lmemiliki nilai (minimum) 0.010000 terdapat pada perusahaan GDST PT.Gunawan Dianjaya Steel Tbk. Pada tahun 2013-2017, dan nilai (maksimum) sebesar 73.93000 terdapat pada perusahaan BAJA PT.Sarana Central Bajatama Tbk. Pada tahun 2013-2017, nilai (median) sebesar 1.620000. Nilai-nilai tersebut menunjukan bahwa respon terhadap Kepemilikan Manajerial adalah antara 0.010000 sampai dengan 73.93000.Sementara standar deviasi Kepemilikan Manajerial sebesar 22.98727menunjukan simpangan data relative besar, karena nilainya yang lebih besar dari pada nilai mean-nya yaitu sebesar 12.47989 .

Data Dewan Direksi memiliki nilai (minimum)2.000000 pada perusahaan YPAS PT.Yanaprima Hastapersada Tbk. Pada tahun 2016-2017 \& ALTO PT.Tri Bayan Tirta Tbk. Pada tahun 2016-2017, dan nilai (maksimum) sebesar 12.00000 pada perusahaan TSPC PT.Tempo Scan Pasific Tbk. pada tahun 2013, nilai (median) sebesar 4.000000Nilai-nilai tersebut menunjukan bahwa respon terhadap Dewan Direksi adalah antara 2.000000sampai dengan 12.00000.Sementara standar deviasi Dewan Direksi sebesar 2.125302 menunjukan simpangan data relative kecil, karena nilainya yang lebih kecil dari pada nilai mean-nya yaitu sebesar 4.810526.

Data kinerja keuangan (ROA) memiliki nilai (minimum) -12.51000 pada perusahaan PTSN PT.Sat Nusa Persada Tbk. padatahun 2017dan nilai (maksimum) sebesar 14.69000 pada perusahaan BTON PT.Betonjaya Manunggal Tbk. Padatahun 2013 (median) sebesar 1.810000 keseluruhan total skor rata-rata ROA3.067789 yang menghasilkan standar deviasi sebesar 5.567039. berdasarkan rata-rata deskriptif terlihat bahwa pada umumnya perusahaan yang dijadikan mean sampel memperoleh ROA sebesar3.067789.

\section{Uji Normalitas}

Hasil uji normalitas pada penelitian ini dapat dilihat dari olahan data yang dilakukan. Data terdistribusi normal dapat dilihat jika nilai probability jarque-bera $>0.05$, jadi data terdistribusi secara normal, sebaliknya jika nilai probability jarque-bera $<0.05$ jadi data tidak terdistribusi secara normal. 
Tabel 4

Uji Normalitas

\begin{tabular}{ll}
\hline Jarque-bera & $\mathbf{0 . 0 5 9 5 2 8}$ \\
Probability & $\mathbf{0 . 9 7 0 6 7 5}$
\end{tabular}

Sumber: outputeviews 8

Dilihat dari tabel 4 diatas dapat dilihat nilai probability lebih besar dari alpha (0.970675 > 0.05 ) yang dapat dirangkumkan bahwa residual normalitas terdistribusi normal.

Tabel 5

Uji Hausman

Chi-Sq.

\begin{tabular}{llll} 
TestSummary & Statistic & Chi-Sq. d.f. Prob. \\
\hline \hline Cross-sectionrandom & 3.892995 & 2 & 0.1428 \\
\hline \hline
\end{tabular}

Sumber : data diolah, eviews 8

Berdasarkan tabel 5 diatas pada data yang telah diuji lanjut ini bisa dilihat nilai probability cross-section random sebesar $0.1428>0,05$ yang artinya $\mathrm{H} 0$ ditolak dan $\mathrm{H} 1$ diterima. Dengan demikian dari model yang baik, random effect yang baik dipakai dari pada model fixed effect. Dari semua uji yang dilakukan yaitu uji chow dan uji hausman telah diperoleh hasil dari model yang terbaik antara Common Effect Model (CEM), Fixed Effect Model (FEM), Random Effect Model (REM).Dari masing-masing hasil estimasi dapat dijelaskan setiap model memiliki nilai signifikan yang berbeda-beda. Dengan demikian, dari ketiga model didapatkan model yang terbaik yaitu random Effect Model (REM).

\section{Regresi Data Panel Model Terbaik}

Pada hasil penelitian ini didapat bahwa model terbaik yang digunakan adalah Random Effect Model (REM). Hasil estimasi dapat dilihat pada tabel berikut :

\section{Tabel 6}

Hasil estimasi RandomEffect Model(REM)

\begin{tabular}{lllll} 
Variabel & CoefficientStd. Error & t-Statistic & Prob. \\
\hline \hline $\mathrm{C}$ & -1.051911 & 2.088883 & -0.503576 & 0.6158 \\
$\mathrm{X} 1$ & -0.015334 & 0.032790 & -0.467634 & 0.6412 \\
$\mathrm{X} 2$ & 0.896173 & 0.375497 & 2.386634 & 0.0191 \\
\hline$\overline{\text { Sumber }: \text { data diolah, }}$ & $\overline{\overline{\text { eviews } 8}}$ & $\overline{ }$
\end{tabular}

Berdasarkan tabel 6 didapatlah persamaan regresi analisis data panel sebagai berikut :

$\mathrm{KK}_{\mathrm{it}}=(\mathbf{- 1 . 0 5 1 9 1 1})+(\mathbf{- 0 . 0 1 5 3 3 4}) \beta_{1} \mathrm{KM}_{\mathrm{it}}+\mathbf{0 . 8 9 6 1 7 3} \beta_{2} \mathrm{DD}$ it $+\mathrm{e}$

Dimana nilai konstanta sebesar -1.051911 memiliki arti bahwa bila Kepemilikan Manajerial, Dewan Direksi, diasumsikan nol, jadi nilai ROA akan menurun sebesar -1.051911. artinya diperoleh pengaruh negatif dewan direksi, kepemilikan manajerialkepada kinerja keuangan (ROA) 
Nilai koefisien Kepemilikan Manajerial (X1) adalah sebesar-0.015334menunjukan hasil yang Negatif yang berarti menurunnya setiap anggota dewan komisaris sebanyak 1 orang maka akan menurunnya ROA sebesar -0.015334. Artinya dapatmempengaruh negatif kepemilikan manajerial terhadap kinerja keuangan

Nilai koefisien Dewan Direksi (X2) adalah sebesar 0.896173 mengatakan hasil yang positif yang berarti setiap meningkatnya anggota dewan direksi sebanyak 1 orang maka akan meningkatkan ROA sebesar 0.896173 . Artinya terdapat pengaruh positif, dewan direksi kepada kinerja keuangan.

\section{Uji Hipotesis}

Pengujian hipotesis pertama yang menunjukkan hasil yang bertolak belakang dengan hipotesis yang dibangun.Pada variabel kepemilikan manajerial menunjukkan nilai $\mathrm{T}_{\text {hitung }}$ $0,467634<\mathrm{T}_{\text {tabel }} 1,985802$ atau probability $0,6412>0,05$ jadi $\mathrm{H}_{1}$ dalam penelitian ini ditolak.. Artinya kepemilikan manajerial pengaruh negative dan tidak signifikan terhadap kinerja keuangan, Untuk variabel dewan direksi menunjukkan nilai $\mathrm{T}_{\text {hitung }} 2,386634>\mathrm{T}_{\text {tabel }}$ 1,985802 atau probability $0,0191<0,05 \mathrm{makaH}_{2}$ dalam penelitian ini diterima. Artinya Dewan direksi pengaruh positif dan signifikan terhadap kinerja keuangan.

\section{PEMBAHASAN}

\section{Pengaruh Kepemilikan Manajerial terhadap Kinerja Keuangan (ROA)}

Dengan demikian dikatakan hipotesis pertama ditolak. Karena darihasil nilai koefisien regresi untuk variabel Kepemilikan Manajerial mempunyai pengaruh negatif dan tidaksignifikan kepada Kinerja Keuangan ROA.

kepemilikan manajerial tidak berpengaruh terhadap kinerja keuangan perusahaan. Menurut Darwis (2009) kepemilikan saham oleh manajer masih sangat kecil sehingga dimungkinkan manajer belum merasakan manfaat dari kepemilikan manajerial tersebut, jadi kepemilikan manajerial tidak berpengaruh terhadap kinerja perusahaan karena Hasil penelitian Maryanah dan Amilin (2011) menyatakan bahwa kepemilikan manajerial berpengaruh signifikan negatif terhadap kinerja keuangan perusahaan. Hasil ini mengindikasikan bahwa baik dewan direksi maupun dewan komisaris memiliki insentif untuk memaksimumkan kesejahteraannya dan konflik yang terjadi di dalam teori keagenan tidak dapat dikurangi (Widyati, 2013).

Hasil penelitian ini tidak mendukung dengan hasil peneliti yang dilaksanakan oleh (Puspitasari \& Ernawati, 2010) yang berjudul Pengaruh Mekanisme Corperate Governence kepada Kinerja Keuangan Badan usaha mengatakan bahwa kepemilikan manajerial berpengaruh signifikan positif kepada kinerja keuangan.

\section{Pengaruh Dewan Direksi Terhadap Kinerja Keuangan (ROA)}

Dari penelitian dikatakan bahwa hipotesis kedua diterima. Karena hasil penelitian ini Mengatakan Dewan Direksi pengaruh positif dan signifikan terhadap kinerja keuangan. Hasil dari penelitian koefisien regresi dari Dewan Direksi berpengaruh positif dan signifikan terhadap kinerja keuangan (ROA).

(Bodroastuti, 2009)kebijakan yang akan diambil baik jangka pendek maupun jangka panjang yang akan ditentukan oleh Dewan Direksi dalam suatu perusahaan.Komunikasi yang baik dengan Jumlah dewan direksi yang lebih sedikit untuk komonikasi antar para direktur, koordinasi yang lebih efektif, dan tindakan yang lebih cepat dalam mengatasi masalah. Putra 
mengatakan bahwa dewan direksi terhadap kinerja keuangan yang mana hasilnya menyimpulkan positif terhadap kinerja keuangan perusahaan

Hasil penelitian ini mendukung penelitian yang dilakukan oleh (Okkyrianto \& Universitas, 2013) yang berjudul Pengaruh Good Corporate Governance terhadap Kinerja Keuangan Perusahaan, hasilnya bahwa variabel dewan direksi mempunyai pengaruh positif signifikan terhadap kinerja keuangan

\section{KESIMPULAN}

Dari hasil penelitian, dapat dirangkumkan bahwa 1) Kepemilikan Manajerial menghasilkan hipotesis bahwa Kepemilikan Manajerial tidak berpengaruh terhadap kinerja keuangan ROA. 2) Dewan direksi berpengaruh positif dan signifikan terhadap kinerja keuangan (ROA)

Untuk peneliti yang akan datang diharapkan bagi peneliti yang akan datang 1) dapat melakukan penelitian dengan menambahkan variabel-variabel GCG yang lain seperti menambahkan variabel Komite Audit, Kepemilikan Institusional, Dewan Komisaris. 2) Menambah alat ukur yang berbeda seperti : Returnon Equity(ROE),Return On Investment (ROI), Net Profit margin(NPM) 3) Menambahkan tahun penelitian agar mendapatkan hasil yang signifikan terhadap variabel yang diteliti.

\section{UCAPAN TERIMAKASIH}

Dalam penyusunan penelitian ini, penulis menyadari bahwa tanpa bimbingan dan bantuan dari berbagai pihak, penulis belum tentu dapat menyelesaikan penelitian ini. Untuk itu ucapan terimakasih yang sebesar-besarnya penulis sampaikan kepada: Bapak Febryandhie Ananda, SE, M.Si selaku ketua STIE "KBP” Padang yang telah memberikan bimbingan dan fasilitas selama penulis menjadi mahasiswi. Ibu Marlina, S. S. T., M.Ak selaku wakil ketua dan sekaligus penasihat akademik angkatan 2013.Ibu Febsri Susanti, SEI, MM selaku ketua program studi manajemen Sekolah Tinggi Ilmu Ekonomi "Keuangan, Perbankan dan Pembangunan" Padang.IbuAminar Sutra Dewi, SE, M.Si selaku Dosen Pembimbing penulis, yang sudah membimbing penulis dari awal skripsi sampai saat sekarang ini, membimbing penulis dengan penuh kesabaran, terimakasih atas segala kesempatan yang Ibu berikan semoga nasehat-nasehat yang Ibu berikan memberi manfaat bagi saya selamanya.

\section{DAFTAR PUSTAKA}

Andriza, R., \& Yusra, I. (2019). Pengaruh kepemilikan manajerial dan kebijakan deviden terhadap kemakmuran Investor dan nilai perusahaan yang tercatat pada indeks LQ45. INARxiv.

Angraini, I., \& Yusra, I. (2019). Pendekatan data panel terhadap return saham: studi empiris pada perusahaan LQ45. INA-Rxiv.

Danil, A., \& Yusra, I. (2019). Pengaruh kausal antara ukuran perusahaan, nilai buku dan likuiditas saham di Bursa Efek Indonesia. INA-Rxiv.

Dewi, A. S. (2012). Pengaruh Corporate Governance Dan Leverage Terhadap Kinerja 


\section{Keuangan Pada Perbankan Yang Terdaftar DI BEI. Kajian Akuntansi Dan Auditing, 7.}

Dewi, A. S., Sari, D., \&Abaharis, H. (2018). Pengaruh Karakteristik Dewan Komisaris Terhadap Kinerja Perusahaan Manufaktur Di Bursa Efek Indonesia. Jurnal Benefita, 3(3).

Gusnita, E., \& Martha, L. (2019). Analisis Struktur Modal Dalam Memoderasi Pengaruh Kepemilikan Manajerial Dan Pertumbuhan Perusahaan Terhadap Nilai Perusahaan Di Indonesia. INA-Rxiv.

Hadya, R. (2014b). Earning Surprise, Ketepatan Waktu Pengumuman Laporan Keuangan Dan Reaksi Pasar. Jurnal Riset Manajemen Dan Akuntansi, 1(2).

Hadya Rizka, N. B. Dan Y. I. (2017). Analisis Efektifitas Pengendalian Biaya, Perputaran Modal Kerja Dan Rentabilitas Ekonomi Menggunakan Regresi Data Panel. Jurnal Pundi, 1(3), 153-166.

Hanafi, D., \& Yusra, I. (2019). Tangibility, liquidity, growth opportunity, dan leverage: studi pada perusahaan terdaftar di Bursa Efek Indonesia. INA-Rxiv, (2001).

Handayani, F., \& Martha, L. (2019). Hubungan Antara Profitabilitas Dengan Nilai Perusahaan Yang Dimoderasi Oleh Corporate Social Responsibility. INA-Rxiv.

Kartin, Y. R., \& Dewi, A. S. (2019). Karakteristik Dewan Komisaris Dan Dampaknya Terhadap Kinerja Keuangan. INA-Rxiv.

Laili, E. S., \& Dewi, A. S. (2019). Dampak Kinerja Keuangan terhadap Corporate Social Responbility pada Sektor Perbankan di Indonesia. INA-Rxiv.

Martha, L. (2018). Peranan Analisis Laporan Keuangan terhadap Pengambilan Keputusan Pemberian Kredit Pada PT. BPR LPN Sungai Rumbai Kabupaten Dharmasraya. INA-Rxiv.

Mulfita, A., \& Yusra, I. (2019). Analisis regresi data panel terhadap likuiditas saham di Indonesia. INA-Rxiv.

Monica, S., \& Dewi, A. S. (2019). Pengaruh Kepemilikan Institusional dan Dewan Komisaris Independen Terhadap Kinerja Keuangan di Bursa Efek Indonesia. INA-Rxiv.

Ningsih, \& Dewi, A. S. (2019). Pengaruh Pelaksanaan Kualitas Audit dan Proporsi Dewan Komisaris Independen terhadap Kinerja Keuangan Perusahaan Property Dan Real Estate di Bursa Efek Indonesia. INA-Rxiv.

Noviawan, R. A., \&Septiani, A. (2013). Pengaruh Mekanisme Corporate Governance Dan Struktur Kepemilikan Terhadap Kinerja Keuangan. Diponegoro Journal Of Accountinf, 2, $1-10$.

Okkyrianto, R., \&Universitas. (2013). Pengaruh Good Corporate Governance Terhadap Kinerja Keuangan Perusahaan. Jurnal Manajemen. 
Pricilia, S., \&Susanto, L. (2017). Pengaruh Kepemilikan Institusional, Kepemilikan Manajerial, Komisaris Independen, Dan Ukuran Dewan Komisaris Terhadap Manajemen Laba Serta Implikasinya Terhadap Kinerja Keuangan Pada Perusahaan Manufaktur Yang Terdaftar Di Bursa Efek Indonesia Periode 201. Jurnal Ekonomi, 22(2), 267-283.

Puspitasari, F., \&Ernawati, E. (2010). Pengaruh Mekanisme Corporate Governance Terhadap Kinerja Keuangan Badan Usaha. Jurnal Manajemen Teori Dan Terapan, 1999(2), 189-215.

Putra, I., \& Yusra, I. (2019). Analisis likuiditas saham menggunakan regresi data panel. INARxiv.

Rivandi, M. (2018). Pengaruh Intellectual Capital Disclosure, Kinerja Keuangan, Dan Kepemilikan Manajerial Terhadap Nilai Perusahaan. Jurnal Pundi, 2(1), 41-54. Https://Doi.Org/10.1360/Zd-2013-43-6-1064

Saputra, J., \& Martha, L. (2019). Analisis Kinerja Keuangan Dan Nilai Perusahaan, Serta Pengaruhnya Terhadap Harga Saham. INA-Rxiv.

Suhartono, \& Yusra, I. (2019). Analisis perbandingan kinerja keuangan bank konvensional dengan bank syariah yang terdaftar di BEI. INA-Rxiv, 1-9.

Sukandar, P. P. (2014). Pengaruh Ukuran Dewan Direksi Dan Dewan Komisaris Serta Ukuran Perusahaan Terhadap Kinerja Keuangan Perusahaan (Vol. 3).

Tertius, M., \&Chris Austitiawan, Y. J. (2010). Pengaruh Good Corporate Governance Terhadap Kinerja Perusahaan Pada Sektor Keuangan. Majalah Ilmiah Informatika,3(2), 47-60.

Wahyudi, R., \& Martha, L. (2019). Analisis Modal Intelektual Dan Kinerja Keuangan Dan Pengaruhnya Terhadap Nilai Perusahaan. INA-Rxiv.

Widyati, M. F. (2013). Pengaruh Dewan Direksi, Komisaris Independen, Komite Audit, Kepemilikan Manajerial Dan Kepemilikan Institusional Terhadap Kinerja Keuangan. Jurnal Ilmu Manajemen, 1(1).

Winarno, W. W. (2015). Analisis Ekonometrika Dan Statistika Dengan Eviews(4th Ed.). Yokyakarta: UPP STIM YKPN.

Wulandari, N. (2017). Analisis Faktor-Faktor Yang Mempengaruhi Inflasi Pada Kota Metropolitan Di Indonesia Dengan Menggunakan Analisis Data Panel. Jurnal Sains Matematika Dan Statistika, 3(2), 34-42.

Yusra, I., Hadya, R., Begawati, N., \& Istiqomah, L. (2019). Panel data model estimation: the effect of managerial ownership, capital structure, and company size on corporate value Panel data model estimation: the effect of managerial ownership, capital structure, and company size on corporate value. Journal of Physics: Conference Series, 1175, 1-6. https://doi.org/10.1088/1742-6596/1175/1/012285 